\title{
PENGARUH INDEPENDENSI AUDITOR DAN FEE AUDITOR TERHADAP KUALITAS AUDIT
}

\author{
Irma Nurmalia ${ }^{1}$; Ridwan Saleh ${ }^{2}$ \\ ${ }^{1}$ STIE Muhammadiyah Jakarta, irmanurmalia92@gmail.com \\ ${ }^{2}$ STIE Muhammadiyah Jakarta, risalah_ak@yahoo.com
}

\begin{abstract}
ABSTRAK
Penelitian ini bertujuan untuk menguji secara empiris pengaruh independensi audit, dan fee audit terhadap kualitas audit. penelitian ini menggunakan variabel independen yaitu independensi auditor dan fee auditor sedangkan variabel dependennya adalah kualitas audit. Sampel dalam penelitian ini adalah auditor yang bekerja pada Kantor Akuntan Publik (KAP) di Wilayah Jakarta Selatan. Pengumpulan sampel dilakukan dengan metode purposive sampling. Pengumpulan data dilakukan dengan menyebar kuesioner langsung ke auditor sebanyak 67 kuesioner. Metode statstik menggunakan Analisis Regresi Linier Berganda, dengan pengujian hipotesis uji statistik t dan uji statistik f. Hasil penelitian ini menunjukan bahwa terdapat pengaruh Indepedensi dan fee auditor secara simultan maupun parsial terhadap kualitas audit pada Kantor Akuntan Publik (KAP) di wilayah Jakarta Selatan.
\end{abstract}

Kata Kunci: Independensi Audit, Fee Audit, dan Kualitas Audit

\begin{abstract}
This research was aimed to examine empirically the effect of audit independence, audit fee and audit quality. The analysis used an independent variable of audit indpendence and audit fee. The dependent variable is audit quality. The sample of this research are auditors who worked on Kantor Akuntan Publik (KAP) Representative of South Jakarta. The sample was conducted by purposive sampling method. Collecting data was conducted by a questionnaire distributed directly to auditors as much 67 questionnaires. The statistical method used was multiplied analysis linear regression, with hypotheses testing of statistic t-tests and hypotheses testing of statistic f-tests. The result of this research showed that audit independence, audit fee and audit quality.. Pressure obedience significantlysimultaneously or partially on audit quality at the Kantor Akuntan Publik (KAP) in the South Jakarta area.
\end{abstract}

Keywords: audit independence, audit fee, and audit quality.

\section{PENDAHULUAN}

Untuk mendapatkan laporan keuangan yang berkualitas maka audit yang dilakukan juga harus berkualitas. Dalam perusahaan yang berskala besar memerlukan jasa profesi auditor independen agar pertanggungjawaban keuangan yang disajikan kepada pihak luar dapat dipercaya sebagai dasar pengambilan keputusan pihak luar. Dari profesi akuntan publik, masyarakat mengharapkan penilaian yang bebas dan tidak memihak terhadap informasi yang disajikan oleh manajemen peusahaan dalam laporan keuangan.Namun adanya kasus yang terjadi dalam manipulasi laporan keuangan telah menyebabkan menurunnya tingkat kepercayaan masyarakat terhadap jasa akuntan profesional publik, permasalahan mengenai rendahnya kualitas audit menjadi sorotan masyarakat dalam beberapa tahun terakhir dengan 


\section{JURNAL AKUNTANSI, Vol. 8, No. 2, November (2019)}

adanya keterlibatan akuntan publik didalamnya. Sehingga beberapa Kantor Akuntan Publik dan Akuntan Publik diberikan sanksi oleh Menteri Keuangan karena melakukan pelanggaran.

Satu sisi auditor ditunjuk manajemen untuk melakukan audit, namun di sisi lain jasa audit dibayar dan ditanggung manajemen. Mekanisme kelembagaan inilah yang mengakibatkan munculnya keterikatan auditor pada klien baik emosional terkait independensinya maupun financial terkait besaran fee auditor, sehingga berimbas terhadap kualitas audit. Khusus di Indonesia, dilakukan penerapan terhadap standar audit sesuai ketetapan IAPI oleh auditor ketika melaksanakan tugasnya. Penerapan standar audit yang benar akan berdampak terhadap peningkatan kualitas audit yang dihasilkan.

Penelitian ini bertujuan untuk menguji pengaruh Independensi dan Fee auditor terhadap Kualitas audit. Ketiga faktor tersebut paling dominan dan dalam kenyataannya sering menjadi masalah bagi kantor akuntan publik, klien maupun pihak ketiga pengguna laporan keuangan klien. Penelitian (Anisa, 2017) menemukan bahwa independensi auditor berpengaruh pada kualitas audit. Penelitian ini sejalan dengan penelitian (Saputra 2012) dan Momon dkk (2018), yang memperlihatkan bahwa independensi berpengaruh positif dan signifikan terhadap kualitas audit. Hasil penelitian berbeda diungkapkan oleh (Hanny, dkk 2011) serta (Rapina, dkk 2011) yang menunjukkan independensi auditor tidak berpengaruh pada kualitas proses audit. Fenomena lainnya yang juga mampu mempengaruhi kualitas audit yaitu kontrak kerjasama dalam hal penentuan besaran fee audit antara auditor dan klien.Penelitian terkait hal tersebut dilakukan (Wuchun 2004) yang menunjukkan bukti berbeda, bahwa fee auditor berpengaruh positif terhadap kualitas audit, sedangkan (Dhaliwan et al. 2008) membuktikan bahwa fee audit secara signifikan mempengaruhi kualitas audit. Berdasarkan uraian tersebut, penulis bermaksud melakukan penelitian lebih lanjut mengenai Pengaruh Independensi Auditor Dan Fee Auditor Terhadap Kualitas Audit.

\section{KAJIAN LITERATUR}

\section{Audit}

Menurut Agoes (2012) Auditing adalah suatu pemeriksaan yang dilakukan secara kritis dan sistematis, oleh pihak yang independen, terhadap laporan keuangan yang telah disusun oleh manajemen, beserta catatan-catatan pembukuan dan bukti-bukti pendukungnya, dengan tujuan untuk dapat memberikan pendapat mengenai kewajaran laporan keuangan tersebut. Kemudian Menurut Arens et al.(2014),Audit adalah akumulasi dan evaluasi bukti tentang informasi untuk menentukan dan melaporkan tingkat korespondensi antara informasi dan kriteria yang ditetapkan. Audit harus dilakukan oleh orang yang kompeten dan independen.

\section{Kualitas Audit}

Menurut Halim (2015) laporan keuangan yang berguna bagi pembuatan keputusan adalah laporan keuangan yang berkualitas (memenuhi kriteria relevansi dan reliabilitas). Para pemakai laporan keuangan lebih yakin terhadap kualitas laporan keuangan suatu perusahaan apabila laporan keuangan tersebut telah audit dan memenuhi kedua kriteria tersebut. Menurut Arenst et al (2011) ada lima prinsip yang harus dipatuhi akuntan publik yaitu : integritas, objektivitas, kompetensi profesional dan kecermatan, kerahasiaan dan perilaku profesional. Selanjutnya menurut Lukman (2015) kualitas audit merupakan suatu hasil akhir dari proses yang sesuai dengan standar pemeriksaan dan pelaporan serta pengendalian mutu yang sudah ditetapkan, pelaksanaan praktik-praktik dalam mengaudit yang bisa dipertanggung jawabkan oleh auditor sebagai bentuk etis profesinya.

\section{Independensi}

Definisi Independensi menurut Siti (2009) independensi dapat dijabarkan sebagai cara pandang yang tidak memihak di dalam pelaksaan pengujan, evaluasi hasi, pemeriksaan, dan penyusunan 
laporan audit. Sikap mental independen tersebut harus meliputi independence in fact dan independence in appreance.Indepedensi dapat dibagi menjadi dua bagian yaitu independence in fact (independensi dalam kenyataan) dan independence in appearance (independensi dalam penampilan).Akuntan publik berkewajiban untuk jujur atau independen tidak hanya kepada manajemen dan pemilik perusahaan, namun juga terhadap kreditur dan pihak lain yang memberi kepercayaan atas profesi akuntan publik (Konvina 2014)..

\section{Fee Auditor}

Menurut Sukrisno Agoes (2012 :46) fee audit merupakan bentuk balas jasa yang auditor berikan kepada klien, dan besarnya fee anggota dapat bervariasi tergantung antara lain: risiko penugasan, kompleksitas jasa yang diberikan, tingkat keahlian yang diperlukan untuk melaksanakan jasa tersebut. Dan auditor dengan yang menerima audit fee lebih tinggi akan merencanakan audit kualitas yang lebih tinggi dibandingkan dengan audit feeyang lebih kecil. $\mathrm{Fee}$ audit adalah besaran biaya yang diterima oleh auditor untuk melaksanakan tugasnya dengan mempertimbangkan beberbagai hal (Halim, 2015:38). Menurut Halim (2015: 108) besaran fee audit ditentukan banyak faktor. Namun pada dasarnya ada 4 faktor yang menentukan besarnya fee audit, yaitu:

1. Karakterisitik keuangan, seperti tingkat penghasilan, laba aktiva, modal, dan lain-lain.

2. Lingkungan, seperti persaingan, pasar tenaga profesional, dan lain-lain.

3. Karakteristik Operasi, seperti jenis industri, jumlah lokasi perusahaan, jumlah lini produk, dan lain-lain.

4. Kegiatan eksternal auditor, seperti pengalaman, tingkat kordinasi dengan internal auditor, dan lain-lain

\section{Kerangka Pemikiran}

Kerangka pemikiran dalam pengaruh Independensi Auditor dan Besaran Fee Auditor Terhadap Kualitas Audit dapat digambarkan sebagai berikut:

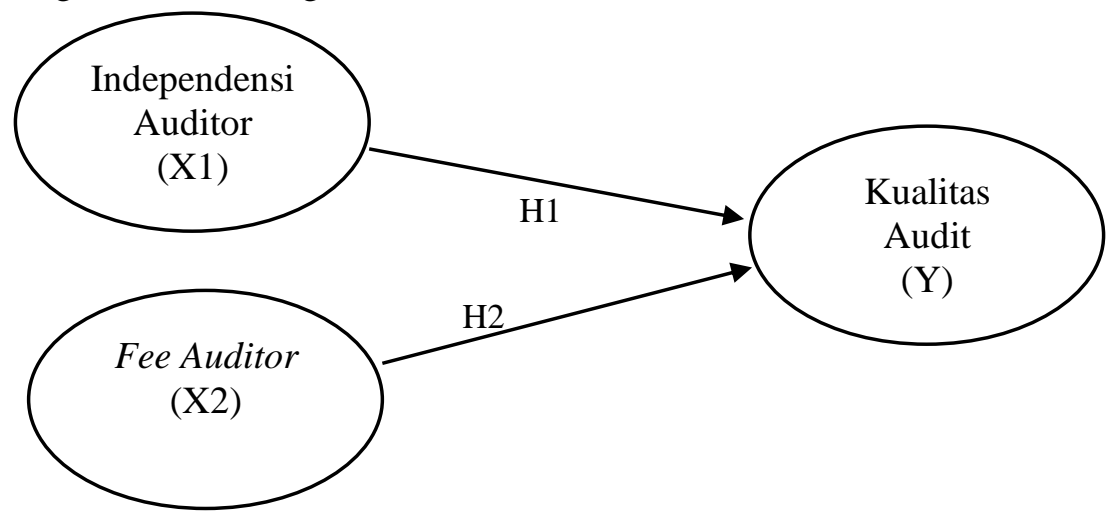

\section{Pengembangan hipotesis}

Hipotesis ini dirumuskan berdasarkan penelitian Ashari (2011) yang menyimpulkan bahwa secara parsial indepdensi berpengaruh secara signifikan (positif) terhadap kualitas audit. Hal ini sejalan dengan Restiyani (2014) menyimpulkan bahwa secara parsial indepedensi auditor berpengaruh secara positif terhadap kualitas audit. Hal yang berbeda dari hasil penelitian oleh Krisnawati (2012) dan Nur'aini (2013) menyimpulkan bahwa indepedensi berpengaruh positif terhadap kualitas audit. Berdasarkan uraian diatas dapat dirumuskan sebagai berikut:

\section{H1: Indepedensi berpengaruh positif terhadap kualitas audit}

Menurut Pratistha dan Widhiyani (2014) auditor dengan fee yang tinggi akan melakukan audit lebih luas dan mendalam terhadap perusahaan klien sehingga kemungkinan kejanggalan-kejanggalan yang ada pada laporan keuangan klien dapat terdeteksi. Penelitian 
yang dilakukan oleh Pratistha dan Widhiyani (2014) menunjukan bahwa besaran fee audit berpengaruh positif dan signifikan terhadap kualitas proses audit.

Penelitian yang dilakukan oleh Rahmania dan Agoes (2014), Zam dan Rahayu (2015) dan didukung dengan penelitian Nuridin dan Widiasari (2016) menunjukan bahwa fee audit berpengaruh positif dan signifikan terhadap kualitas audit. Ini berarti bahwa fee audit yang lebih tinggi maka semakin baik kualitas audit yang dihasilkannya. Berdasarkan temuan yang telah dijelaskan di atas, maka dapat dirumuskan hipotesis sebagai berikut:

\section{H2: Fee audit berpengaruh positif terhadap kualitas audit.}

\section{METODOLOGI PENELITIAN}

Penelitian ini termasuk dalam kategori penelitian kausal dengan menggunakan metode kuantitatif. Metode penelitian yang digunakan dalam penelitian ini menggunakan metode analisis kuantitatif sebab data yang digunakan merupakan data empiris dan variabel yang digunakan mempunyai satuan yang dapat diukur. Sampel yang disebar dalam penelitan ini adalah 67 orang auditor. Tekhnik pengambilan sampel yang dilakukan dengan dengan menggunakan metode pendektan Purposive sampling untuk menentukan sampel dari populasi yang memenuhi kriteria sesuai dengan yang penulis kehendaki, yaitu minimal sudah mengaudit selama satu tahun.Hal ini dilakukan agar jawaban kusisioner dapat terjawab dengan baik pada subjek yang tepat dan berkompeten dibidangnya.Sampel yang diambil adalah staf/pejabat pemeriksa dan auditor yang bekerja pada Kantor Akuntan Publik (KAP) yang berada di wilayah Jakarta Selatan.

\section{HASIL DAN PEMBAHASAN Karakteristik Responden}

Dari daftar pertanyaan yang dibagikan, menunjukan bahwa auditor yang terdapat di KAP di Jakarta Selatan mayoritas berjenis kelamin Pria yaitu sebanyak 37 orang atau 55,2\% dan yang berjenis kelamin wanita yaitu sebanyak 30 orang atau 44,8\%. Responden berusia 25 tahun yaitu sebesar $52.2 \%$ (35 orang). Sedangkan distribusi usia responden yang lain yaitu usia 26-35 tahun sebesar 37,3\% 25 orang), usia antara 36-45 tahun sebesar 7,5\% (5 orang), dan usia diatas >45 tahun sebesar 3\% (2 orang). Pendidikan responden adalah Diploma (D3) yaitu sebanyak 9 orang atau 13,4\%, Sarjana (S1) yaitu sebanyak 52 orang atau 77,6 \%. Sedangkan distribusi pendidikan yang lain yaitu Pasca Sarjana (S2) sebanyak 6 orang atau 9\%, dan Doktor (S3) sebanyak 0 orang atau $0 \%$. Jabatan responden adalah Partner yaitu sebanyak 1 orang atau $1,5 \%$, Manager yaitu sebanyak 3 orang atau $4,5 \%$. Sedangkan distribusi jabatan yang lain yaitu Supervisor sebanyak 4 orang atau 6\%, Senior Auditor sebanyak 18 orang atau 26,9\% dan Junior Auditor sebanyak 41 orang atau 61,6\%. Pengalaman Kerja responden adalah 1-5 Tahun yaitu sebanyak 51 orang atau 76,1\% . Sedangkan distribusi Pengalaman Kerja yang lain yaitu 610 Tahun sebanyak 13 orang atau $19,4 \%$, dan $>10$ Tahun sebanyak 3 orang atau $4,5 \%$.

\section{Analisa Uji Validitas}

Bila penelitian tersebut tidak sesuai apa yang terjadi maka objek, maka data tersebut dapat dinyatakan tidak valid. Suatu instrument atau koesioner dapat dinyatakan valid apabila Koevisien korelasi (dalam kolom corrected item total correlation) melebihi 0,3. 


\section{JURNAL AKUNTANSI, Vol. 8, No. 2, November (2019)}

Tabel 1. Uji Validitas

Independensi Auditor

Item-Total Statistics

\begin{tabular}{|l|r|r|r|r|r|}
\hline & $\begin{array}{c}\text { Scale Mean if } \\
\text { Item Deleted }\end{array}$ & $\begin{array}{c}\text { Scale Variance } \\
\text { if Item Deleted }\end{array}$ & $\begin{array}{c}\text { Corrected Item- } \\
\text { Total } \\
\text { Correlation }\end{array}$ & $\begin{array}{c}\text { Squared } \\
\text { Multiple } \\
\text { Correlation }\end{array}$ & $\begin{array}{c}\text { Cronbach's } \\
\text { Alpha if Item } \\
\text { Deleted }\end{array}$ \\
\hline X1.1 & 34.851 & 22.583 & .822 & .823 & .913 \\
X1.2 & 34.836 & 22.927 & .793 & .905 & .915 \\
X1.3 & 34.836 & 22.776 & .815 & .930 & .913 \\
X1.4 & 34.896 & 24.216 & .747 & .661 & .918 \\
X1.5 & 35.090 & 23.689 & .755 & .746 & .917 \\
X1.6 & 34.896 & 24.156 & .683 & .530 & .922 \\
X1.7 & 35.149 & 24.371 & .657 & .629 & .923 \\
X1.8 & 35.045 & 24.589 & .673 & .703 & .922 \\
X1.9 & 35.030 & 24.969 & .658 & .849 & .923 \\
\hline
\end{tabular}

Sumber: Hasil Output spss

Berdasarkan tabel 1 diatas, hasil uji validitas terhadap Indepedensi auditor memperlihatkan semua nilai dalam kolom corrected item total correlation) melebihi 0,3 berarti pernyataan tersebut dinyatakan valid.

Tabel 2. Uji Validitas

Fee Auditor

Item-Total Statistics

\begin{tabular}{|l|r|r|r|r|r|}
\hline & $\begin{array}{c}\text { Scale Mean if } \\
\text { Item Deleted }\end{array}$ & $\begin{array}{c}\text { Scale Variance } \\
\text { if Item Deleted }\end{array}$ & $\begin{array}{c}\text { Corrected Item- } \\
\text { Total } \\
\text { Correlation }\end{array}$ & $\begin{array}{c}\text { Squared } \\
\text { Multiple } \\
\text { Correlation }\end{array}$ & $\begin{array}{c}\text { Cronbach's } \\
\text { Alpha if Item } \\
\text { Deleted }\end{array}$ \\
\hline X2.1 & 25.134 & 15.239 & .740 & .652 & .902 \\
X2.2 & 25.090 & 15.446 & .821 & .800 & .891 \\
X2.3 & 25.104 & 16.004 & .771 & .767 & .897 \\
X2.4 & 25.343 & 16.562 & .766 & .682 & .898 \\
X2.5 & 25.313 & 17.400 & .664 & .587 & .908 \\
X2.5 & 25.149 & 16.190 & .732 & .592 & .901 \\
X2.7 & 25.284 & 17.146 & .692 & .668 & .906 \\
\hline
\end{tabular}

Sumber: Hasil output spss

Berdasarkan tabel 2 diatas, hasil uji validitas terhadap variabel Fee auditor memperlihatkan semua nilai dalam kolom corrected item total correlation melebihi 0,3 berarti pernyataan tersebut dinyatakan valid. Dengan demikian pernyataan tersebut dinyatakan valid. 
Tabel 3. Uji Validitas Kualitas Audit

\begin{tabular}{|l|r|r|r|r|r|}
\hline & $\begin{array}{c}\text { Scale Mean if } \\
\text { Item Deleted }\end{array}$ & $\begin{array}{c}\text { Scale Variance } \\
\text { if Item Deleted }\end{array}$ & $\begin{array}{c}\text { Corrected Item- } \\
\text { Total } \\
\text { Correlation }\end{array}$ & $\begin{array}{c}\text { Squared } \\
\text { Multiple } \\
\text { Correlation }\end{array}$ & $\begin{array}{c}\text { Cronbach's } \\
\text { Alpha if Item } \\
\text { Deleted }\end{array}$ \\
\hline Y1.1 & 65.657 & 71.047 & .734 & .742 & .953 \\
Y1.2 & 65.358 & 68.870 & .825 & .849 & .951 \\
Y1.3 & 65.403 & 70.305 & .641 & .688 & .955 \\
Y1.4 & 65.433 & 70.583 & .736 & .784 & .953 \\
Y1.5 & 65.388 & 70.120 & .820 & .912 & .951 \\
Y1.6 & 65.493 & 71.133 & .753 & .799 & .952 \\
Y1.7 & 65.552 & 71.584 & .735 & .863 & .953 \\
Y1.8 & 65.567 & 71.492 & .698 & .737 & .953 \\
Y1.9 & 65.567 & 71.431 & .729 & .824 & .953 \\
Y1.10 & 65.433 & 71.886 & .693 & .725 & .953 \\
Y1.11 & 65.522 & 71.193 & .707 & .699 & .953 \\
Y1.12 & 65.343 & 70.653 & .742 & .806 & .952 \\
Y1.13 & 65.448 & 71.009 & .751 & .700 & .952 \\
Y1.14 & 65.194 & 70.795 & .739 & .721 & .953 \\
Y1.15 & 65.433 & 69.310 & .799 & .848 & .951 \\
Y1.16 & 65.299 & 70.031 & .749 & .757 & .952 \\
\hline
\end{tabular}

Sumber: Hasil output spss

Berdasarkan tabel 3 diatas, hasil uji validitas terhadap variabel kualitas audit memperlihatkan semua nilai dalam kolom corrected item total correlation melebihi 0,3 berarti pernyataan tersebut dinyatakan valid. Dengan demikian pernyataan tersebut dinyatakan valid.

\section{Analisa Uji Reliablitas}

Suatu instrument atau kuesioner dapat dinyatakan reliabel apabila pada kolom Cronbach"s Alpha memiliki nilai diatas 0,6.

Dari pengujian yang dilakukan, diperoleh hasil sebagai berikut:

Tabel 4

Uji Reliabilitas

Independensi Auditor

Reliability Statistics

\begin{tabular}{|c|c|c|}
\hline $\begin{array}{c}\text { Cronbach's } \\
\text { Alpha }\end{array}$ & $\begin{array}{c}\text { Cronbach's } \\
\text { Alpha Based on } \\
\text { Standardized } \\
\text { Items }\end{array}$ & N of Items \\
\hline .927 & .927 & 9 \\
\hline
\end{tabular}




\section{Tabel 5}

Uji Reliabilitas

Fee Auditor

Reliability Statistics

\begin{tabular}{|r|r|r|}
\hline $\begin{array}{c}\text { Cronbach's } \\
\text { Alpha }\end{array}$ & $\begin{array}{c}\text { Cronbach's } \\
\text { Alpha Based on } \\
\text { Standardized } \\
\text { Items }\end{array}$ & \\
\hline .914 & .915 & N of Items \\
\hline
\end{tabular}

Sumber: Output spss

\section{Tabel 6}

Uji Reliabilitas

Kualitas Audit

Reliability Statistics

\begin{tabular}{|c|c|c|}
\hline $\begin{array}{c}\text { Cronbach's } \\
\text { Alpha }\end{array}$ & $\begin{array}{c}\text { Cronbach's } \\
\text { Alpha Based on } \\
\text { Standardized } \\
\text { Items }\end{array}$ & \\
\hline .955 & N of Items \\
\hline \multicolumn{2}{|c|}{ Sumber: Output spss } & 16 \\
\hline
\end{tabular}

Berdasarkan tabel diatas, hasil uji validitas terhadap variabel independen, fee dan kualitas audit dengan menggunakan tehnik alpa croncbach pada kolom Cronbach"s Alpha memiliki nilai $0,927,0,914$ dan 0,955 yang artinya masih diatas 0,7 .Dengan demikian pernyataan tersebut dinyatakan reliable.

\section{Analisis Regresi Berganda}

Model Regresi Linier Berganda digunakan untuk menjawab hipotesis yaitu apakah indepedensi, fee auditor secara simultan dan parsial berpengaruh terhadap kualitas audit.

Rumus persamaan regresi linier berganda dibuat sebagai berikut:

$$
\mathrm{KA}=\alpha+\beta 1 \mathrm{IA}+\beta 2 \mathrm{FA}+\mathrm{e}
$$

Keterangan

$\mathrm{KA}=$ Kualitas audit $\alpha \quad=$ Nilai Intersep (Konstan)

$\beta \quad=$ Koefisien arah regresi

IA $\quad=$ Independen Auditor

$\mathrm{FA}=$ Fee Auditor

$\mathrm{e} \quad=$ Error

Hasil analisis regresi linier berganda dapat ditunjukkan seperti pada tabel sebagai berikut : 


\section{JURNAL AKUNTANSI, Vol. 8, No. 2, November (2019)}

Tabel 7
Hasil analisis regresi berganda
Coefficients

a. Dependent Variable: Y

sumber: Hasil Output spsss

Dari hasil regresi didapatkan koefisien regresi yang dapat dibuat persamaan regresi sebagai berikut :

$$
\begin{aligned}
& \mathrm{Y}=\alpha+\beta 1 \mathrm{X} 1+\beta 2 \mathrm{X} 2+\mathrm{e} \\
& \mathrm{Y}=11.370+0,1.226+0, .348+\mathrm{e}
\end{aligned}
$$

Artinya konstanta sebesar 11.370 artinya jika indepedensi(X1) dan Fee auditor(X2) bernilai tetap, maka kualitas audit bernilai sebesar 11.370 Koefisien X1 $=1.226$ artinya jika independensi meningkat 1 satuan, maka kualitas audit meningkat sebesar 0,1.226 Koefisien X2 $=0, .348$ artinya jika kompetensi meningkat satu satuan, maka kualitas audit meningkat sebesar $0, .348$.

\section{Uji Asumsi Klasik}

\section{Uji Normalitas}

Uji Normalitas dapat dilihat pada tabel dan gambar dibawah ini:

\section{Gambar 1}

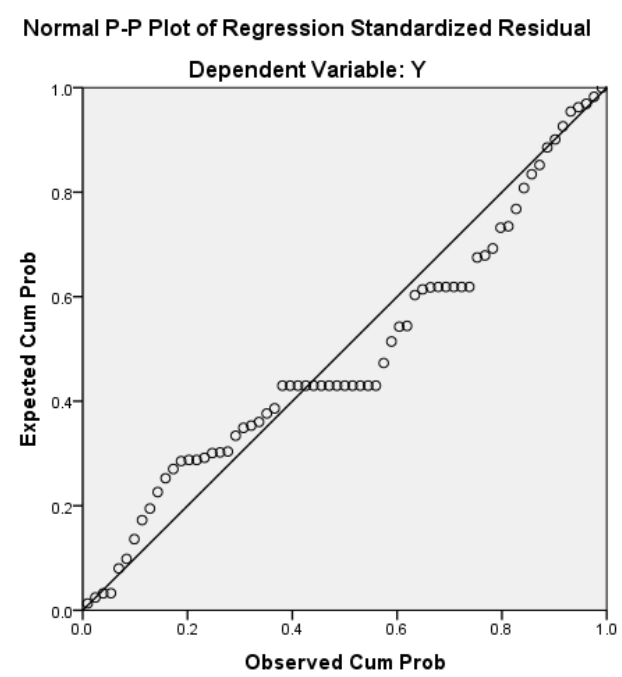

Sumber: Hasil output spss

Berdasarkan gambar diatas, terlihat bahwa grafik P-P plot nilaidata yang menyebar di sekitar garis diagonal dan mengikuti garis diagonal atau grafik histogramnya dan menunjukkan adanya pola distribusi normal. Oleh karena itu, model regresinya memenuhi asumsi normalitas. 


\section{JURNAL AKUNTANSI, Vol. 8, No. 2, November (2019)}

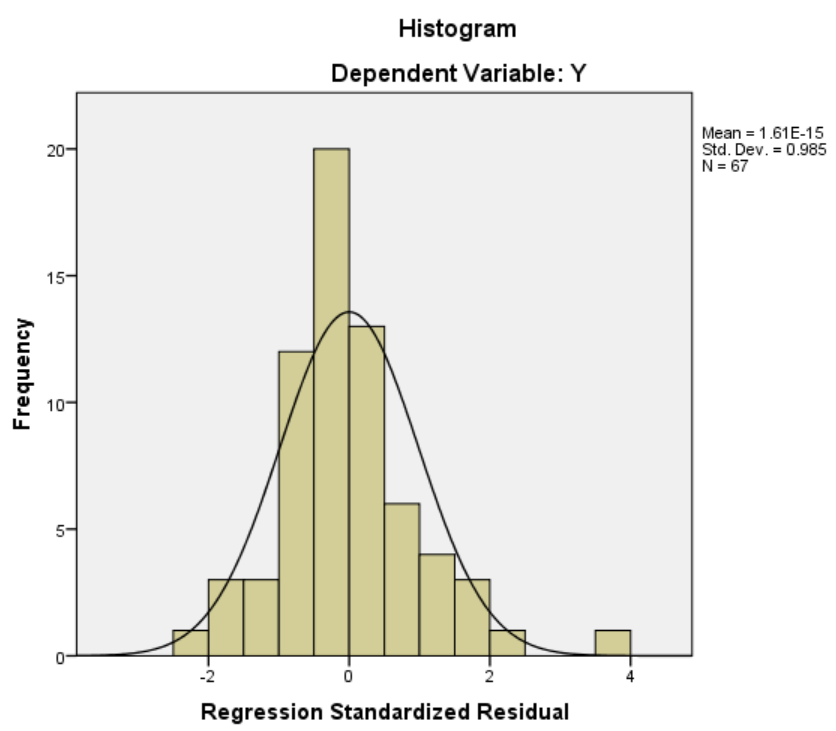

Gambar 2

Sumber: Hasil Output SPSS

Berdasarkan gambar grafk diatas, dapat diketahui bahwa nilai ST.Dev = $0,985<0,05$ yang artinya data pada penelitian ini berdistribusi normal.

\section{Uji Heterosktisidas}

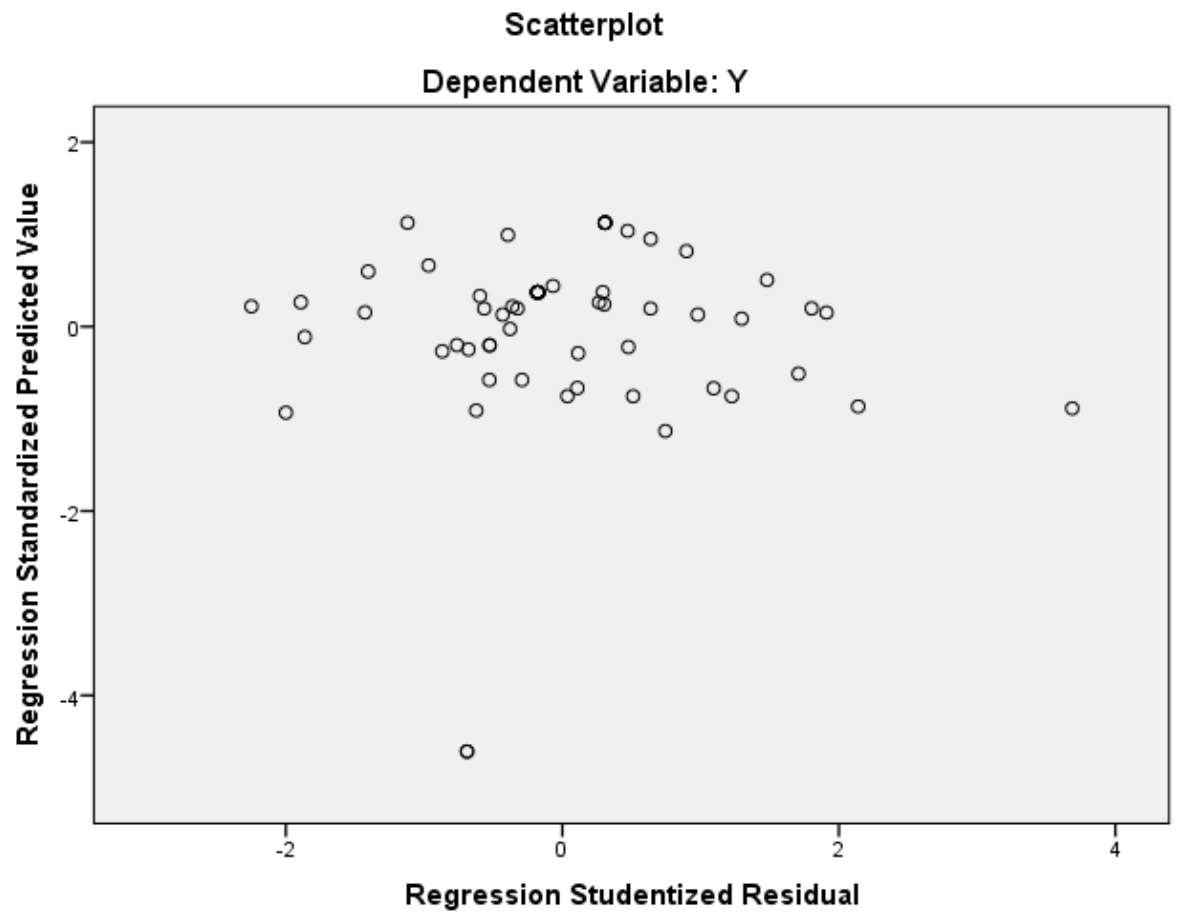

Gambar 3

Sumber: Hasil output spss 
Dilihat dari gambar pada hasil output SPSS diatas, terlihat varians dari residu tersebut tidak mempunyai pola tertentu atau tersebar secara acak diatas dan dibawah angka 0 pada sumbu $\mathrm{Y}$, sehingga regresi tidak mengandung unsur heteroskedastisitas.

Uji Multikolnearitas

Tabel 8

Uji Multikolinearitas

Coefficients $^{\mathrm{a}}$

\begin{tabular}{|ll|r|r|r|r|}
\hline \multirow{2}{*}{ Model } & \multicolumn{4}{|c|}{ Correlations } \\
\cline { 3 - 6 } & \multicolumn{1}{|c|}{ Partial } & Part & Tolerance & \multicolumn{1}{c|}{ VIF } \\
\hline 1 & & & & \\
& (Constant) & .757 & .545 & .531 & 1.882 \\
\cline { 2 - 6 } & $\mathrm{X} 1$ & .270 & .132 & .531 & 1.882 \\
\hline
\end{tabular}

Sumber: Hasil output spss

Hasil nilai Variance Inflantion Factor(VIF) dengan menggunakan SPSS 22.0 yaitu sebagai berikut 1.882X1 (independensi) $1.882 \mathrm{X} 2$ (Fee Auditor).Hasil ini berarti variabel terbebas dari asumsi klasik multikolonieritas, karena hasilnya lebih kecil dari 10.

\section{Uji Hipotesis}

Uji signifikan parameter individual (Uji statistik t)

Tabel 9

Uji t parsial

Coefficients $^{\mathbf{a}}$

\begin{tabular}{|c|c|c|c|c|c|c|c|}
\hline \multirow{2}{*}{\multicolumn{2}{|c|}{ Model }} & \multicolumn{2}{|c|}{ Unstandardized Coefficients } & \multirow{2}{*}{$\begin{array}{c}\begin{array}{c}\text { Standardized } \\
\text { Coefficients }\end{array} \\
\text { Beta }\end{array}$} & \multirow[b]{2}{*}{$\mathrm{T}$} & \multirow[b]{2}{*}{ Sig. } & \multirow{2}{*}{$\begin{array}{l}\text { Correlation } \\
\text { s } \\
\text { Zero-order }\end{array}$} \\
\hline & & $\mathrm{B}$ & Std. Error & & & & \\
\hline \multirow[t]{3}{*}{1} & (Constant) & 11.370 & 3.956 & & 2.874 & .005 & \\
\hline & $\mathrm{X} 1$ & 1.226 & .132 & .748 & 9.260 & .000 & .872 \\
\hline & $\mathrm{X} 2$ & .348 & .155 & .181 & 2.246 & .028 & .693 \\
\hline
\end{tabular}

a. Dependent Variable: Kualitas_audit

Sumber: Hasil output spss

$$
\begin{aligned}
\mathrm{T} \text { tabel } & =\mathrm{x} / 2 ; \mathrm{n}-\mathrm{k}-1 / \mathrm{df} \text { residual (tabel anova) } \\
& =(0,05 / 2) ; \mathrm{n}-\mathrm{k}-1 / 64 \\
& =0,025 ; 64 \\
& 1,997(\text { Lihat T-tabel })
\end{aligned}
$$

$>$ Hasil uji $\mathrm{t}$ menunjukkan $\mathrm{t} 1=9,260>\mathrm{t}$ tabel 1,997 dan nilai sig $0,00<0,05$ berarti Ho ditolak dan Ha diterima yang menunjukan bahwa varibel independensi auditor berpengaruh posiif dan signifikan terhadap kualitas audit.

$>$ Hasil uji t2 hitung menunjukkan $\mathrm{t} 2=2,246>\mathrm{t}$ tabel 1,996 dan nilai sig 0,028 $<0,05$ yang berarti Ho ditolak dan Ha diterima yang menunjukan bahwa variabel fee auditor berpengaruh positif dan signifikan terhadap kualitas audit.

\section{Uji Hipotesis Simultan (UJi F)}

Uji $\mathrm{F}$ dikatakan terdapat pengaruh yang signifikan secara simultan apabila nilai $\mathrm{F}$ hitung $>\mathrm{F}$ tabel 


\section{JURNAL AKUNTANSI, Vol. 8, No. 2, November (2019)}

Tabel 10

Uji F (Simultan)

ANOVA $^{\mathrm{a}}$

\begin{tabular}{|c|c|c|c|c|c|c|}
\hline & & $\begin{array}{l}\text { Sum of } \\
\text { Squares }\end{array}$ & $\mathrm{df}$ & Mean Square & $\mathrm{F}$ & Sig. \\
\hline \multirow[t]{3}{*}{1} & Regression & 4119.954 & 2 & \multirow{3}{*}{$\begin{array}{r}2059.977 \\
18.352\end{array}$} & \multirow[t]{3}{*}{112.249} & \multirow[t]{3}{*}{$.000^{\mathrm{b}}$} \\
\hline & Residual & 1174.523 & 64 & & & \\
\hline & Total & 5294.478 & 66 & & & \\
\hline
\end{tabular}

a. Dependent Variable: Y

b. Predictors: (Constant), X2, X1

$$
\begin{array}{rlrl}
\text { Df } 1 & =\mathrm{k}-1 & \text { Df } 2 & =\text { Jumlah sampel }-\mathrm{df} 1 \\
& =3-1=2 \quad & 67-2=65
\end{array}
$$

Hasil uji hipotesis simultan (Uji F) dapat dilihat pada tabel diatas yaitu dengan Nilai $\mathrm{F}$ hitung $=112,249$ dan $\mathrm{F}$ tabel $=3,1381$, Hal ini berarti bahwa $\mathrm{F}$ hitung > F tabel yang menandakan bahwa variabel independensi auditor dan Fee auditor berpengaruh secara simultan terhadap kualitas audit

Uji R Simultan

Tabel 11

Uji R

Model Summary ${ }^{\mathrm{b}}$

\begin{tabular}{|l|r|r|r|r|r|r|r|}
\hline & & & & & \multicolumn{3}{|c|}{ Change Statistics } \\
\cline { 5 - 8 } Model & $\mathrm{R}$ & $\mathrm{R}$ Square & $\begin{array}{c}\text { Adjusted R } \\
\text { Square }\end{array}$ & $\begin{array}{c}\text { Std. Error of } \\
\text { the Estimate }\end{array}$ & $\begin{array}{c}\text { R Square } \\
\text { Change }\end{array}$ & F Change & df1 \\
\hline 1 & $.882^{\mathrm{a}}$ & .778 & .771 & 4.284 & .778 & 112.249 & 2 \\
\hline
\end{tabular}

Berdasarkan tabel diatas, menunjukkan nilai $\mathrm{R}$ Square $=0,778$ yang berarti bahwa kualitas audit dipengaruhi oleh independensi dan fee auditor sebesar 77,8 persen. Sisanya 22,2 persen dipengaruhi factor lain yang tidak diteliti.

\section{PEMBAHASAN}

\section{Pengaruh Independensi Auditor terhadap Kualitas Audit}

Berdasarkan perhitungan statistik dapat disimpulkan bahawa variabel Independensi Auditor (X1) berpengaruh positif terhadap Kualitas Audit (Y) secara parsial. Hal ini dapat dilihat dari Hasil uji t yang menunjukkan $\mathrm{t} 1=9,260>\mathrm{t}$ tabel 1,997 dan nilai sig $0,00<0,05$ berarti Ho ditolak dan Ha diterima. Sedangkan jika dilihat dari Uji F variabel Independensi Auditor (X1) berpengaruh secara simultan terhadap Kualitas Audit (Y), dikarnakan nilai F hitung $>\mathrm{F}$ tabel yakniF hitung $=112,249>\mathrm{F}$ tabel 3,1381. Dengan demikian hipotesis H1 dalam penelitian ini yang menunjukan bahwa varibel independensi auditor berpengaruh positif dan signifikan terhadap kualitas audit baik didukung. Hasil penelitian ini sejalan dengan Restiyani (2014) menyimpulkan bahwa secara parsial indepedensi auditor berpengaruh secara positif terhadap kualitas audit. Hal ini juga didukung oleh penelitian Krisnawati (2012) dan Nur'aini (2013), juga Momon d.k.k (2018) yang menyimpulkan bahwa indepedensi 


\section{JURNAL AKUNTANSI, Vol. 8, No. 2, November (2019)}

berpengaruh positif terhadap kualitas audit. Berdasarkan uraian diatas dapat dirumuskan sebagai berikut:

\section{Pengaruh Fee Audit Terhadap Kualitas AudiT}

Berdasarkan perhitungan statistik dapat disimpulkan bahawa variabel Fee Auditor (X2) berpengaruh positif terhadap Kualitas Audit (Y) secara parsial. Hal ini dapat dilihat dari Hasil uji t2 hitung menunjukkan $\mathrm{t} 2=2,246>\mathrm{t}$ tabel 1,996 dan nilai sig 0,028 $<0,05$ yang berarti Ho ditolak dan Ha diterima. Sedangkan jika dilihat dari Uji F, variabel Fee Auditor (X2) berpengaruh secara simultan terhadap Kualitas Audit (Y), dikarnakan nilai F hitung > F tabel yakniF hitung $=112,249>\mathrm{F}$ tabel $=3,1381$. Dengan demikian hipotesis $\mathrm{H} 2$ dalam penelitian ini yang menunjukan bahwa variabel $f e e$ auditor berpengaruh positif dan signifikan terhadap kualitas audit didukung. Hasil penelitian ini sependapat dengan Pratistha dan Widhiyani (2014) dimana auditor dengan fee yang tinggi akan melakukan audit lebih luas dan mendalam terhadap perusahaan klien sehingga kemungkinan kejanggalan-kejanggalan yang ada pada laporan keuangan klien dapat terdeteksi. Hasil ini juga sejalan dengan penelitian yang dilakukan oleh Pratistha dan Widhiyani (2014) yang menunjukan bahwa besaran fee audit berpengaruh positif dan signifikan terhadap kualitas proses audit, penelitian yang dilakukan oleh Rahmania dan Agoes (2014), Zam dan Rahayu (2015) dan didukung dengan penelitian Nuridin dan Widiasari (2016) menunjukan bahwa fee audit berpengaruh positif dan signifikan terhadap kualitas audit. Ini berarti bahwa fee audit yang lebih tinggi maka semakin baik kualitas audit yang dihasilkannya.

Dari hasil penelitian diketahui bahwa kualitas audit pada auditor di Kantor Akuntan Publik di Wilayah Jakarta Selatan dapat ditentukan oleh faktor fee dan independensinya dalam koefisien determinasi R2 adalah $77,8 \%$. Sisanya $22,2 \%$ dipengaruhi faktor lain yang tidak diteliti diluar model penelitian ini

\section{PENUTUP}

\section{Kesimpulan}

Terdapat pengaruh positif signifikan secara parsial maupun simultan Independensi terhadap Kualitas Audit pada Kantor akuntan publik (KAP) di wilayah Jakarta Selatan. Terdapat pengaruh positif baik secara parsial maupun simultan fee auditor terhadap kualitas audit pada Kantor akuntan publik (KAP) di wilayah Jakarta Selatan. Terdapat pengaruh Indepedensi dan fee auditor secara simultan terhadap kualitas audit pada Kantor Akuntan Publik (KAP) di wilayah Jakarta Selatan. Semakin tinggi tingkat independensi auditor maka Kualitas audit semakin baik, dan semakin tinggi tingkat fee auditor maka Kualitas audit semakin baik.

Adapun saran bagi peneliti berikutnya yang akan melakukan penelitian dengan topik sejenis disarankan hendaknya menggunakan atau menambahkan variabel lain yang belum dimasukkan dalam penelitian ini karena masih banyak variabel lain yang dapat mempengaruhi kualitas audit sehingga dapat memberikan perbandingan yang baik kepada pihak - pihak yang memerlukan. Bagi auditor diharapkan harus meningkatkan sikap indepedensinya tanpa terpengaruh oleh hubungan atasan dan bawahan dalam suatu instansi. Auditor harus membaca dan memahami Kode Etik yang sudah ditetapkan oleh IAI (Ikatan Akuntan Publik). Bagi akademisi, penelitian ini diharapkan dapat memberikan pengetahuan khususnya bagi penulis sendiri tentang Indepedensi dan Fee auditor pengaruhnya terhadap Kualitas audit.

\section{REFERENSI}

Aanwijzing,. 2016. Mengenal Pengertian Auditing (Pemeriksaan) https://www.aanwijzing.com/2016/06/mengenal-pengertian-auditing-pemeriksaan.html Diaskes 2019. 


\section{JURNAL AKUNTANSI, Vol. 8, No. 2, November (2019)}

Abizar, (2018) Pengaruh Independensi Dan Kompetensi Auditor Terhadap Kualitas Audit (Studi Kasus Pada Kantor Akuntan Publik (KAP) Di Wilayah Jakarta Pusat Dan Jakarta Selatan). Skripsi. Jurusan Akuntansi Sekolah Tinggi Ilmu Ekonomi Muhammadiyah Jakarta.

Sukrisno, A . (2008). Auditing: Pemeriksanaan Akuntansi oleh Kantor AkuntanPublik. Jilid I. Jakarta: Lembaga Penerbit FE Universitas Indonesia.

Samtirta, A. (2018). MODUL 2 Struktur Organisasi Kantor Akuntan Publik (KAP) Dan Job Description. https://www.scribd.com/document/376305868/MODUL-2-StrukturOrganisasi-Kantor-Akuntan-Publik-KAP-Dan-Job-Description. Diaskes 2019

Anisa, S.W. (2017) Pengaruh Independensi, Etika Profesi Dan Integritas Auditor Terhadap Kualitas Audit Di Kantor Akuntan Publik Wilayah Daerah Istimewa Yogyakarta. Skripsi. Fakultas Ekonomi Universitas Negeri Yogyakarta

Arens,Alvin A.,Randal J.Elder, Mark S.Beasley.(2004). Auditing and Assurance Service: An Integrated Approach $\left(9^{\text {th }}\right.$ ed.). Jakarta: PT Indeks Kelompok Gramedia.

Arulrudiana,. 2014. Pengertian Independensi Akuntan Publik. http://arulrudianaaa.blogspot.com/2014/06/pengertian-independensi-akuntanpublik.html. Diakses 2019.

Auditorinternal,. 2010. Kode Etik Auditor Internal. http://auditorinternal.com/2010/01/19/kodeetik-auditor-internal/diakses 2019.

Aziz,. 2016. Independensi Auditor Filosofi Auditing. http://azizrengee.blogspot.co.id/2016/04/independensi-auditor-filosofi-auditing.html ， diakses 2018

Halim, Abdul. (2003). Auditing (Dasar - Dasar Audit Laporan keuangan). Yogyakarta:UPPAMPYKPN.

Hestanto,. 2018. Kualitas Audit dan Fee Audit. https://www.hestanto.web.id/kualitas-audit-danfee-audit/ Diakses 2019.

Institut Akuntan Publik Indonesia,. (2017). Directory Kantor Akuntan Publik Dan Akuntan Publik 2017.

Mulyadi.(1998). Auditing. Jakarta: SalembaEmpat.

Momon, Rachbini, W., Amilin. 2018. Faktor Penentu Kualitas Audit di Kantor Akuntan Publik DKI Jakarta. Jurnal Akuntansi, Vol. 7 No. 2. Pp. 85-99.

Prasistha,K.D.,dan Widhiyani,N.L.S.(2014). Pengaruh independensi auditor dan besaran fee audit terhadap kualitas proses audit. ISSN: 2302-8556. Jurnal Akuntansi Universitas Udayana 6.3:419-428.

Rahayu, S.K., dan Suhayati, E. (2010). Auditing: Konsep dasar dan pedoman pemeriksaan akuntansi publik. Yogyakarta: Graha Ilmu.

Rahayu, T., dan Suryono, B. (2016). Pengaruh independensi auditor, etika auditor, dan pengalaman auditor terhadap kualitas audit. Jurnal Ilmu Dan Riset Akuntansi. Vol. 5.4. April.

Wati,L.N. (2018). Metodologi Penelitian Dan Terapan aplikasi SPSS, EVIEWS,SmartPLS, dan AMOS. Bandung: Mujahid Press. 